\title{
Evaluation of Performance of Tourism Industry Companies listed in Istanbul Stock Exchange (BIST) by TOPSIS Methodology
}

\section{Erdal Yilmaz}

Samsun Ondokuz Mayıs University | eyilmaz@ omu.edu.tr

\section{Tunay Aslan}

Independent Researcher | tunay_aslan@hotmail.com

Volume 7 No 2 (2017) ｜ ISSN 2158-8708 (online) | DOI 10.5195/emaj.2017.136 | http://emaj.pitt.edu |

\begin{abstract}
To evaluate the operations of the companies in the past years and to make forecasts about the future, it is important to evaluate and analyze their financial performance. In this study, the financial performances of tourism enterprises operating in Istanbul Stock Exchange for 2013-2016 are compared with TOPSIS method. As a result of the research, it is determined that the best performances are observed in 2014, 2015 and 2016 for MALT and in 2013 for METUR.
\end{abstract}

Keywords: Tourism, Borsa Istanbul, Istanbul Stock Exchange, BIST, TOPSIS

\section{$(\mathrm{cc}) \mathrm{EY}$}

New articles in this journal are licensed under a Creative Commons Attribution 3.0 United States License.

\section{UILIS D-Sunte}

This journal is published by the University Library System of the University of Pittsburgh as part of its D-Scribe Digital Publishing Program, and is cosponsored by the University of Pittsburgh Press. 
Evaluation of Performance of Tourism Industry Companies listed in Istanbul Stock Exchange (BIST) by TOPSIS Methodology

\section{Erdal Yılmaz \\ Tunay Aslan}

\section{Introduction}

Tourism industry, which is an important sector of the economy, is increasing its importance day by day. Tourism sector produces economic units that aim to meet the needs by producing tourism services and to obtain the final profit. In order for tourism businesses to survive, continue their activities and reach their goals, it is very important to use this information that is obtained when evaluating, measuring and making future plans for financial performance. The evaluation of financial performance includes investors and lenders. Evaluation of financial performance also provides important information to decision makers such as managers in making past evaluations and planning for the future.
In this study, the financial performances of the tourism enterprises operating in the tourism sector, which has an important place in the Turkish economy and traded in the Istanbul Stock Exchange (BIST) are evaluated. The TOPSIS method, which is one of the Multiple Criteria Decision Making techniques is used in evaluating the financial performance. The TOPSIS method is an important method that helps to take decisions by choosing between multiple alternatives with converting a number of criteria to a single score on performance evaluation. In the analysis, various financial ratios were calculated on the basis of the financial statements of seven tourism companies traded in the BIST between 2013-2016 and the financial performances of the companies were compared by evaluating these ratios by TOPSIS method.

\section{Literature Review}

The evaluation of the financial performance of companies is a subject that has been studied in the literature. Programs such as ELECTRE and TOPSIS are used to evaluate and compare financial performances. There are other studies evaluating the financial performance of tourism companies as well. A summary of the literature on which company performance is assessed by TOPSIS method is presented in the table below.

\begin{tabular}{|c|c|c|c|c|c|c|}
\hline NO & Publication Title & Author(s) & Year & Journal Name & $\begin{array}{c}\text { Purpose and Method of } \\
\text { Study }\end{array}$ & Study Findings \\
\hline 1 & $\begin{array}{l}\text { Türk Hisse Senedi } \\
\text { Emeklilik Yatırım } \\
\text { Fonlarının Çok } \\
\text { Kriterli } \\
\text { Performans } \\
\text { Değerlendirmesi: } \\
\text { Topsıs Metodu }\end{array}$ & $\begin{array}{l}\text { Alptekin ve } \\
\text { Ş1klar }\end{array}$ & 2009 & $\begin{array}{l}\text { Dumlupınar } \\
\text { Üniversitesi } \\
\text { Sosyal Bilimler } \\
\text { Dergisi }\end{array}$ & $\begin{array}{l}\text { To assess the performance } \\
\text { of Turkish stock pension } \\
\text { mutual funds, which is an } \\
\text { important investment } \\
\text { instrument in terms of } \\
\text { individual investors, } \\
\text { TOPSIS method as a } \\
\text { multi-criteria decision } \\
\text { making method was used } \\
\text { for January 2007- } \\
\text { December } 2008 \text { period. }\end{array}$ & $\begin{array}{l}\text { Fund performance evaluation } \\
\text { generally uses traditional } \\
\text { performance measurement techniques } \\
\text { such as Sharpe ratio, M2 performance } \\
\text { measure, Sortino ratio, Treynor index, } \\
\text { T2 performance measure, Jensen } \\
\text { index and Valuation Ratio. The } \\
\text { TOPSIS method takes into account } \\
\text { the comparison of multiple criteria } \\
\text { and gives more meaningful results in } \\
\text { the performance evaluation of stock } \\
\text { pension mutual funds. Therefore; by } \\
\text { using the TOPSIS method, a single } \\
\text { performance criterion has been } \\
\text { achieved in which traditional } \\
\text { performance measures are evaluated } \\
\text { together. }\end{array}$ \\
\hline
\end{tabular}




\begin{tabular}{|c|c|c|c|c|c|c|}
\hline 2 & $\begin{array}{l}\text { TOPSIS } \\
\text { Yöntemine göre } \\
\text { Performans } \\
\text { değerleme }\end{array}$ & $\begin{array}{l}\text { Yükçü ve } \\
\text { Atağan }\end{array}$ & 2010 & $\begin{array}{l}\text { Muhasebe ve } \\
\text { Finansman } \\
\text { Dergisi }\end{array}$ & $\begin{array}{l}\text { TOPSIS method was used } \\
\text { to compare the } \\
\text { performance of different } \\
\text { businesses. }\end{array}$ & $\begin{array}{l}\text { In performance appraisal, the use of } \\
\text { financial indicators prevents the } \\
\text { making of subjective decisions. } \\
\text { However, comparing financial results } \\
\text { with each other can be problematic } \\
\text { for the decision maker. Because, the } \\
\text { usefulness of the methods can differ } \\
\text { according to the expectations of the } \\
\text { enterprises without performance } \\
\text { evaluation. At this point, like the } \\
\text { other multiple decision making } \\
\text { methods, the TOPSIS method allows } \\
\text { the decision maker to make a more } \\
\text { objective assessment because it can } \\
\text { combine different evaluation options } \\
\text { into a common pavilion. }\end{array}$ \\
\hline 3 & $\begin{array}{l}\text { TOPSIS Yöntemi } \\
\text { Kullanılarak } \\
\text { Finansal ve } \\
\text { Finansal Olmayan } \\
\text { Oranlara Göre } \\
\text { Performans } \\
\text { Değerlendirilmesi, } \\
\text { Şehirlerarası } \\
\text { Otobüs Sektöründe } \\
\text { Bir Uygulama }\end{array}$ & $\begin{array}{l}\text { Soba } \\
\text { Eren }\end{array}$ & 2011 & $\begin{array}{l}\text { Sosyal } \\
\text { Ekonomik } \\
\text { Araştırmalar } \\
\text { Dergisi }\end{array}$ & $\begin{array}{l}\text { Anadolu Transportation } \\
\text { Incorporated companies, } \\
\text { which has entered } \\
\text { transportation sector } \\
\text { recently in Turkey is } \\
\text { evaluated for } 4 \text { years in } \\
\text { terms of financial and non- } \\
\text { financial data using } \\
\text { TOPSIS method. }\end{array}$ & $\begin{array}{l}\text { A total of } 14 \text { criteria have been } \\
\text { determined under the three main } \\
\text { headings of production, marketing } \\
\text { and operation in the four-year } \\
\text { financial structured study of the } \\
\text { Anadolu Ulaşı Anonim Sirketi, } \\
\text { which has entered the transportation } \\
\text { sector in Turkey in a recent period. } \\
\text { With these } 14 \text { criteria, success } \\
\text { rankings were made over } 4 \text { years. In } \\
\text { this context, the most successful year } \\
\text { is } 2007 \text { (100\%). Successful } \\
\text { percentages of the other years are } \\
2009(84 \%), 2010 \text { (79\%) and } 2008 \\
(21 \%) \text { respectively. }\end{array}$ \\
\hline 4 & $\begin{array}{l}\text { İMKB'ye Kayıtlı } \\
\text { Taş ve Toprak } \\
\text { Alanında Faaliyet } \\
\text { Gösteren } \\
\text { İşletmemelerin } \\
\text { Performanslarının } \\
\text { TOPSIS Yöntemi } \\
\text { İle } \\
\text { Değerlendirilmesi }\end{array}$ & Soba vd & 2011 & $\begin{array}{l}\text { İstanbul Ticaret } \\
\text { Üniversitesi } \\
\text { Dergisi }\end{array}$ & $\begin{array}{l}\text { To measure the } \\
\text { performances of firms } \\
\text { operating in the stone and } \\
\text { land area, TOPSIS method } \\
\text { was used for financial data } \\
\text { between } 2006 \text { and } 2010 .\end{array}$ & $\begin{array}{l}\text { According to TOPSIS method, the } \\
\text { results of the financial statements of } \\
\text { the enterprises are consistent with } \\
\text { each other. The method presented in } \\
\text { this study has provided a useful } \\
\text { approach in determining the } \\
\text { performance evaluations by } \\
\text { comparing the operating companies in } \\
\text { the same field for the identical criteria } \\
\text { over the years. }\end{array}$ \\
\hline 5 & $\begin{array}{l}\text { İMKB'ye Kote } \\
\text { Bilişim Sektörü } \\
\text { Şirketlerinin } \\
\text { Finansal } \\
\text { Performanslarının } \\
\text { TOPSIS Yöntemi } \\
\text { ile } \\
\text { Değerlendirilmesi }\end{array}$ & $\begin{array}{l}\text { Türkmen ve } \\
\text { Çağıl }\end{array}$ & 2012 & $\begin{array}{l}\text { Maliye Finans } \\
\text { Yazıları }\end{array}$ & $\begin{array}{l}\text { To analyze the financial } \\
\text { performances of these } \\
\text { firms using the TOPSIS } \\
\text { method which is one of the } \\
\text { most criteria decision } \\
\text { making techniques, } \\
\text { financial tables of twelve } \\
\text { firms registered in the } \\
\text { Istanbul Stock Exchange } \\
\text { and operating in the } \\
\text { Information Sector were } \\
\text { used. }\end{array}$ & $\begin{array}{l}\text { When TOPSIS results are analyzed, it } \\
\text { is seen that PKART company is the } \\
\text { best performing company in 2007- } \\
2010 \text { period. KAREL and ARENA } \\
\text { companies are consistently } \\
\text { performing well. ESCOM has } \\
\text { improved its financial performance in } \\
\text { recent years despite its poor } \\
\text { performance in first years. It has been } \\
\text { determined that LINK has performed } \\
\text { poorly in } 2007 \text { with the lowest } \\
\text { performance in } 2007 \text { and has } \\
\text { performed well again in the following } \\
\text { years, failing to maintain this } \\
\text { performance. LOGO company had a } \\
\text { good performance in } 2007 \text {, and it was } \\
\text { observed that in the following years } \\
\text { performance rankings were at the } \\
\text { bottom of the list. }\end{array}$ \\
\hline 6 & $\begin{array}{l}\text { Finansal } \\
\text { Performansın } \\
\text { TOPSIS Çok } \\
\text { Kriterli Karar } \\
\text { Verme Yöntemi İle } \\
\text { Belirlenmesi: Ana } \\
\text { Metal Sanayi } \\
\text { İşletmeleri Üzerine } \\
\text { Bir Uygulama }\end{array}$ & $\begin{array}{l}\text { Uygurtürk } \\
\text { ve Korkmaz }\end{array}$ & 2012 & $\begin{array}{l}\text { Eskişehir } \\
\text { Osmangazi } \\
\text { Üniversitesi } \\
\text { İBFF Dergisi }\end{array}$ & $\begin{array}{l}\text { To analyze the financial } \\
\text { performances } \\
\text { enterprises, of } \\
\text { method was used for } \\
\text { financial tables belonging } \\
\text { to the period of } 2006-2010 \\
\text { of } 13 \text { basic metal industry } \\
\text { enterprises traded on } \\
\text { Istanbul Stock Exchange } \\
\text { (ISE). }\end{array}$ & $\begin{array}{l}\text { It has been found that the } \\
\text { performance scores of the companies } \\
\text { operating in the basic metal industry } \\
\text { generally vary during the analysis } \\
\text { period. }\end{array}$ \\
\hline
\end{tabular}




\begin{tabular}{|c|c|c|c|c|c|c|}
\hline 7 & 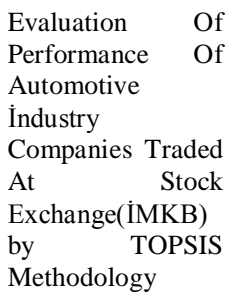 & Şenel vd & 2012 & $\begin{array}{l}\text { Interdisciplinary } \\
\text { Journal Of } \\
\text { Contemporary } \\
\text { Research İn } \\
\text { Business }\end{array}$ & $\begin{array}{l}\text { Evaluating the financial } \\
\text { data of } 17 \text { companies } \\
\text { operating in the automotive } \\
\text { field between } 2009 \text { and } \\
2011 \text { with the TOPSIS } \\
\text { method }\end{array}$ & $\begin{array}{l}\text { As a result of the study, it was } \\
\text { observed that the financial indicators } \\
\text { of companies Fedaral mogul and } \\
\text { İzmit Piston Pin Manufacturing were } \\
\text { more successful than companies like } \\
\text { Sabanc1 Tire, Steel Rope, Demirtaş } \\
\text { Cast,Karsan in all } 3 \text { periods. }\end{array}$ \\
\hline 8 & $\begin{array}{l}\text { Hava Taşımacılığı } \\
\text { Sektöründe } \\
\text { TOPSIS Yöntemi } \\
\text { ile Finansal } \\
\text { Performans } \\
\text { Değerlendirilmesi }\end{array}$ & $\begin{array}{l}\text { Ömürberk } \\
\text { ve Kınay }\end{array}$ & 2013 & $\begin{array}{l}\text { Süleyman } \\
\text { Demirel } \\
\text { Üniversitesi } \\
\text { İktisadi ve İdari } \\
\text { Bilimler }\end{array}$ & $\begin{array}{l}\text { To evaluate the financial } \\
\text { performances of an airline } \\
\text { company (ABC) operating } \\
\text { in the Istanbul Stock } \\
\text { Exchange (BIST) and an } \\
\text { airway company (XYZ) } \\
\text { operating in the Frankfurt } \\
\text { Stock Exchange, the } \\
\text { TOPSIS method was used. }\end{array}$ & $\begin{array}{l}\text { Both airline companies are superior to } \\
\text { each other in terms of different } \\
\text { performance indicators. However, in } \\
\text { order to make a holistic evaluation, } \\
\text { TOPSIS method, which is one of the } \\
\text { most popular decision making } \\
\text { techniques, has been used. The } \\
\text { TOPSIS method is preferred because } \\
\text { all criteria that are essential for } \\
\text { evaluation can be subject to joint } \\
\text { valuation. For this reason, the } \\
\text { performances of airline companies } \\
\text { were evaluated using the weight of } \\
\text { performance indicators in the study. } \\
\text { As a result of the performance } \\
\text { evaluation made by TOPSIS method, } \\
\text { it is concluded that the companies } \\
\text { traded in Istanbul Stock Exchange are } \\
\text { more successful. }\end{array}$ \\
\hline 9 & $\begin{array}{l}\text { İmalat } \\
\text { Sektörlerinin } \\
\text { Finansal } \\
\text { Performanslarının } \\
\text { TOPSIS ve } \\
\text { ELECTRE } \\
\text { Yöntemleri İle } \\
\text { Değerlendirilmesi }\end{array}$ & $\begin{array}{l}\text { Ömürberk } \\
\text { ve Mercan }\end{array}$ & 2014 & $\begin{array}{l}\text { Çankırı } \\
\text { Karatekin } \\
\text { Üniversitesi } \\
\text { İktisadi ve İdari } \\
\text { Bilimler } \\
\text { Fakültesi Dergisi }\end{array}$ & $\begin{array}{l}\text { To evaluate financial } \\
\text { performances using } \\
\text { various financial ratios of } \\
\text { the manufacturing sector, } \\
\text { TOPSIS and ELECTRE } \\
\text { methods were used. }\end{array}$ & $\begin{array}{l}\text { In the solutions; S9 "coke and refined } \\
\text { petroleum products manufacturing } \\
\text { sector" is in the first place for both } \\
\text { methods. The proportions in which } \\
\text { coke and refined petroleum products } \\
\text { have the first place in the } \\
\text { manufacturing sector are important. }\end{array}$ \\
\hline 10 & $\begin{array}{l}\text { Finansal Krizlerin } \\
\text { BİST Metal Eşya } \\
\text { Endeksinde } \\
\text { Faaliyet Gösteren } \\
\text { Firmaların Mali } \\
\text { Performanslarına } \\
\text { Etkisinin TOPSIS } \\
\text { Yöntemi r İle } \\
\text { Ölçülmesi }\end{array}$ & Topaloğlu & 2014 & $\begin{array}{l}\text { Yönetim ve } \\
\text { Ekonomi } \\
\text { Araştırmaları } \\
\text { Dergisi }\end{array}$ & $\begin{array}{l}\text { The } 18 \text { companies } \\
\text { operating in the Bursa } \\
\text { Istanbul Metal Goods and } \\
\text { Machinery Index and the } \\
\text { data for the 2000-2012 } \\
\text { period of these companies } \\
\text { were obtained by the } \\
\text { TOPSIS method in } 2001 \\
\text { and } 2008 \text { to examine } \\
\text { within the context of } \\
\text { crises. }\end{array}$ & $\begin{array}{l}\text { As a result of the analysis, Federal } \\
\text { Mogul İzmit Piston ve Pim Üretim } \\
\text { Tesisleri A.Ş. is the company with the } \\
\text { most stable financial performance } \\
\text { among the companies in the sector. } \\
\text { The financial performance scores of } \\
\text { other companies for the } 2000-2012 \\
\text { period and the resulting fluctuations } \\
\text { in their rankings have been } \\
\text { determined. Moreover, it can be said } \\
\text { that the fragility caused by the } 2008 \\
\text { crisis is at a lower level than the } 2001 \\
\text { crisis. }\end{array}$ \\
\hline 11 & $\begin{array}{l}\text { TOPSIS } \\
\text { Yönteminin } \\
\text { Finansal } \\
\text { Performans } \\
\text { Göstergesi Olarak } \\
\text { Kullanılabilirliği }\end{array}$ & $\begin{array}{l}\text { Saldanli ve } \\
\text { Sirma }\end{array}$ & 2014 & $\begin{array}{l}\text { Marmara } \\
\text { Üniversitesi } \\
\text { Öneri Dergisi }\end{array}$ & $\begin{array}{l}\text { This study was run to } \\
\text { evaluate whether the } \\
\text { TOPSIS method can help } \\
\text { in the presentation of a } \\
\text { large number of financial } \\
\text { data of the decision makers } \\
\text { in the decision-making } \\
\text { process. }\end{array}$ & $\begin{array}{l}\text { As a result of the study, it has been } \\
\text { concluded that the TOPSIS method } \\
\text { scores are not capable of helping } \\
\text { investment decisions for publicly } \\
\text { traded companies. However, if the } \\
\text { method is developed, it will be very } \\
\text { helpful to the investor at the decision } \\
\text { stage and will enter the literature as } \\
\text { an important financial evaluation } \\
\text { criterion. }\end{array}$ \\
\hline 12 & $\begin{array}{lr}\text { BİST’de } & \text { İşlem } \\
\text { Gören } & \text { Turizm İşl. } \\
\text { TOPSIS } & \text { Yöntemi } \\
\text { ile } \quad \text { Finansal } \\
\text { Performanslarının } \\
\text { Değerlendirilmesi }\end{array}$ & $\begin{array}{l}\text { Özçelik ve } \\
\text { Kandemir }\end{array}$ & 2015 & $\begin{array}{l}\text { Balıkesir } \\
\text { Üniversitesi } \\
\text { Sosyal Bilimler } \\
\text { Enstitüsü Dergisi }\end{array}$ & $\begin{array}{l}\text { This research was } \\
\text { conducted to analyze the } \\
\text { financial performances of } \\
\text { tourism companies with } \\
\text { TOPSIS method by taking } \\
\text { advantage of financial } \\
\text { ratios. }\end{array}$ & $\begin{array}{l}\text { Through the TOPSIS method, } \\
\text { multiple ratios were evaluated } \\
\text { together, and the performance } \\
\text { evaluation measure was reduced to a } \\
\text { single coefficient, and general } \\
\text { rankings were made between the } \\
\text { enterprises. }\end{array}$ \\
\hline
\end{tabular}




\begin{tabular}{|c|c|c|c|c|c|c|}
\hline 13 & $\begin{array}{l}\text { TOPSIS } \\
\text { Performance } \\
\text { Evaluation } \\
\text { Measures and } \\
\text { Relation Between } \\
\text { Financial Ratios } \\
\text { and stock Returns }\end{array}$ & Özen vd & 2015 & $\begin{array}{l}\text { Journal of } \\
\text { Economics, } \\
\text { Finance and } \\
\text { Accounting }\end{array}$ & $\begin{array}{l}\text { This study was run to } \\
\text { determine the financial } \\
\text { performance of companies } \\
\text { with TOPSIS method and } \\
\text { to measure the relationship } \\
\text { between these performance } \\
\text { and financial ratios as well } \\
\text { as returns of stocks. }\end{array}$ & $\begin{array}{l}\text { There was no relationship between } \\
\text { TOPSIS performance scores and } \\
\text { stock returns. When we look at the } \\
\text { relationship between financial ratios } \\
\text { and stock returns, there is generally } \\
\text { no correlation between variables in } \\
\text { three out of four firms. Only } \\
\text { statistically significant positive } \\
\text { relationships were found between } \\
\text { profitability ratios of an operator and } \\
\text { market returns. The study results } \\
\text { reveal that stock prices are mainly } \\
\text { determined by external factors, } \\
\text { especially in small businesses. }\end{array}$ \\
\hline 14 & $\begin{array}{l}\text { Financial } \\
\text { Performance of } \\
\text { Pension } \\
\text { Companies } \\
\text { Operating in } \\
\text { Turkey with } \\
\text { TOPSIS Analysis } \\
\text { Method }\end{array}$ & $\begin{array}{l}\text { İşseveroğlu } \\
\text { ve Sezer }\end{array}$ & 2015 & $\begin{array}{l}\text { International } \\
\text { Journal of } \\
\text { Academic } \\
\text { Research in } \\
\text { Accounting, } \\
\text { Finance and } \\
\text { Management } \\
\text { Sciences }\end{array}$ & $\begin{array}{l}\text { This research was } \\
\text { conducted to analyze the } \\
\text { financial performance of } \\
\text { the pension companies for } \\
\text { the years 2008-2012 using } \\
\text { the TOPSIS method. }\end{array}$ & $\begin{array}{l}\text { As a result of the study, the } \\
\text { performance results did not show } \\
\text { much change during the analysis } \\
\text { period. }\end{array}$ \\
\hline 15 & $\begin{array}{lr}\text { AHP } & \text { Temelli } \\
\text { TOPSIS } & \text { ve } \\
\text { ELECTRE } & \\
\text { Yöntemiyle } \\
\text { Muhasebe Paket } \\
\text { Programı Seçimi }\end{array}$ & Tunca vd & 2015 & $\begin{array}{l}\text { Niğde } \\
\text { Üniversitesi } \\
\text { İktisadi ve İdari } \\
\text { Bilimler } \\
\text { Fakültesi Dergisi }\end{array}$ & $\begin{array}{l}\text { This study was run to } \\
\text { evaluate the most } \\
\text { appropriate accounting } \\
\text { package program choice } \\
\text { using TOPSIS and } \\
\text { ELECTRE methods } \\
\text { considering r many } \\
\text { qualitative and quantitative } \\
\text { criteria. }\end{array}$ & $\begin{array}{l}\text { For the weights of the criteria that } \\
\text { were effective in the selection process } \\
\text { of the accounting package program in } \\
\text { the study, the consistency rate of the } \\
\text { evaluations made with the AHP } \\
\text { technique was examined and it was } \\
\text { found that the results were reliable. } \\
\text { Criteria with the highest importance } \\
\text { were the ability to report and ease of } \\
\text { use of menus, respectively. }\end{array}$ \\
\hline 16 & $\begin{array}{l}\text { Performance } \\
\text { Evaluation of } \\
\text { Electricity } \\
\text { Generation } \\
\text { Companies Traded } \\
\text { on BIST according } \\
\text { to the Financial } \\
\text { Parameters } \\
\text { through the } \\
\text { Application of } \\
\text { TOPSIS Method }\end{array}$ & $\begin{array}{l}\text { İlkuçar ve } \\
\text { Çifçi }\end{array}$ & 2016 & $\begin{array}{l}\text { International } \\
\text { Journal of Social } \\
\text { Sciences and } \\
\text { Education } \\
\text { Research }\end{array}$ & $\begin{array}{l}\text { This research was done to } \\
\text { analyze the financial ratios } \\
\text { of the electricity } \\
\text { companies traded in the } \\
\text { BIST for } 2015 \text { by using the } \\
\text { TOPSIS method. }\end{array}$ & $\begin{array}{l}\text { The results of the financial analysis } \\
\text { using the TOPSIS method showed } \\
\text { that AYEN was the most successful } \\
\text { electricity company and AKENER } \\
\text { was the most unsuccessful company. }\end{array}$ \\
\hline 17 & $\begin{array}{l}\text { Finansal } \\
\text { TOPSIS ranların } \\
\text { Siralaması ile } \\
\text { Yıllık Getiriler } \\
\text { Arasındaki Illişki: } \\
\text { Tekstil Imalatı } \\
\text { Sektörü Üzerine } \\
\text { Bir Uygulama }\end{array}$ & $\begin{array}{l}\text { Temizel ve } \\
\text { Bayçelebi }\end{array}$ & 2016 & $\begin{array}{l}\text { Anadolu } \\
\text { Üniversitesi } \\
\text { Sosyal Bilimler } \\
\text { Dergisi }\end{array}$ & $\begin{array}{l}\text { The purpose of this study } \\
\text { was to evaluate and } \\
\text { compare the financial } \\
\text { performances of } \\
\text { companies operating in } \\
\text { textile sector using } \\
\text { TOPSIS method. }\end{array}$ & $\begin{array}{l}\text { Between the years 2011-2014, there } \\
\text { was no significant relationship } \\
\text { between the TOPSIS rankings of } \\
\text { firms. }\end{array}$ \\
\hline 18 & $\begin{array}{l}\text { Yönetim } \\
\text { Kararlarında } \\
\text { Geçerli Maliyet } \\
\text { Analizlerinde } \\
\text { Alternatif Bir } \\
\text { Yöntem: Bulanık } \\
\text { TOPSIS Yöntemi }\end{array}$ & $\begin{array}{l}\text { Mihriban } \\
\text { COŞKUN } \\
\text { ARSLAN }\end{array}$ & 2017 & $\begin{array}{l}\text { Gazi İktisat ve } \\
\text { İşletme Dergisi }\end{array}$ & $\begin{array}{l}\text { In the implementation } \\
\text { section, the decision of the } \\
\text { operator to renew the } \\
\text { technology and increase } \\
\text { capacity; the selection } \\
\text { problem of the existing } \\
\text { machine and the two CNC } \\
\text { machines to be purchased } \\
\text { were analyzed using the } \\
\text { fuzzy TOPSIS method } \\
\text { with valid cost analysis. }\end{array}$ & $\begin{array}{l}\text { As a result, a common solution to the } \\
\text { selection of the same machine was } \\
\text { found in both methods. In this case, } \\
\text { the fuzzy TOPSIS method can be } \\
\text { used as an alternative to valid cost } \\
\text { analysis in making management } \\
\text { decisions. }\end{array}$ \\
\hline
\end{tabular}




\begin{tabular}{|c|c|c|c|c|c|c|}
\hline 19 & $\begin{array}{l}\text { TOPSIS Yöntemi } \\
\text { ile Finansal } \\
\text { Performans } \\
\text { Değerlendirmesi: } \\
\text { XUTEK Üzerinde } \\
\text { Bir Uygulama }\end{array}$ & $\begin{array}{l}\text { Orçun ve } \\
\text { Eren }\end{array}$ & 2017 & $\begin{array}{l}\text { Muhasebe } \quad \text { ve } \\
\text { Finansman } \\
\text { Dergisi }\end{array}$ & $\begin{array}{l}\text { This study analyzed } \\
\text { financial performances of } \\
\text { technology companies } \\
\text { traded in Istanbul } \\
\text { Exchange (BIST) using } \\
\text { TOPSIS method. }\end{array}$ & $\begin{array}{l}\text { The most successful companies in } \\
\text { terms of performance between } 2010 \\
\text { and } 2015 \text { were ASELS, LINK, } \\
\text { ARMDA, LINK, INDES and } \\
\text { DGATE. Financial performance of } \\
\text { the technology companies traded in } \\
\text { Istanbul Stock Exchange is analyzed } \\
\text { by TOPSIS method. }\end{array}$ \\
\hline 20 & $\begin{array}{l}\text { BİST'te Ana Metal } \\
\text { Sanayi Endeksinde } \\
\text { Faaliyet Gösteren } \\
\text { İşletmelerin } \\
\text { Finansal } \\
\text { Performans } \\
\text { Ölçümü:2011- } \\
2015 \text { Dönemi }\end{array}$ & Şit vd & 2017 & $\begin{array}{l}\text { Süleyman } \\
\text { Demirel } \\
\text { Üniversitesi } \\
\text { Vizyoner } \\
\text { Dergisi, }\end{array}$ & $\begin{array}{l}\text { This paper evaluated the } \\
\text { financial performances of } \\
\text { the companies in BIST } \\
\text { Main Metal Index } \\
\text { (XMANA) by TOPSIS } \\
\text { method. }\end{array}$ & $\begin{array}{l}\text { As a result of the analysis carried out, } \\
\text { it is seen that the firms operating in } \\
\text { the sector have different financial } \\
\text { performances and the performances } \\
\text { of the firms vary between the } 2011- \\
2015 \text { period. }\end{array}$ \\
\hline
\end{tabular}

\section{Purpose and Content}

The purpose of this study is to evaluate and compare the financial performances of companies operating in tourism sector and traded in BIST using the TOPSIS method. Due to the fact that tourism enterprises are affected by global economic, social and political issues, we do not engage in companies that do not operate in the tourism sector. The names of the tourism companies traded in the BIST and their codes are shown in Table 2. The dataset of the study constitutes the financial statements of the tourism companies traded in the BIST for 4 years between 2013-2016. The information used to calculate the financial ratios was derived from the annual financial statements published on official websites of the BIST and Public Disclosure Platform (KAP) (BIST, 2017; KAP, 2017). The 9 generally accepted financial ratios selected from the liquidity, financial structure, activity and profitability ratios and obtained from the financial tables were taken from Public Disclosure Platform (KAP) (kap.gov.tr). They are shown in Table 3. Although studies have been carried out analyzing financial performances of tourism enterprises previously traded in the BIST, the absence of a research study covering the 2013-2016 period increases the importance of our paper.

Table 2: Businesses Operating in the Tourism Sector (BIST)

\begin{tabular}{|c|c|}
\hline $\begin{array}{c}\text { BIST } \\
\text { Operation }\end{array}$ & Business Name \\
\hline AVTUR & $\begin{array}{c}\text { AVRASYA PETROL VE TURISTLIK } \\
\text { TESISLER YATIRIMLAR A.Ş }\end{array}$ \\
\hline MAALT & $\begin{array}{c}\text { MARMARIS ALTINYUNUS TURISTTIK } \\
\text { TESISLER A.Ş. }\end{array}$ \\
\hline MARTI & MARTI OTEL İŞLETMELERI A.Ş \\
\hline METUR & $\begin{array}{c}\text { METEMTUR OTELCILIK VE TURİZM } \\
\text { ISSSETMELERİ ANONIM ŞIRKETİ }\end{array}$ \\
\hline NTTUR & NET TURIZMM TICARET VE SANAYİ A.Ş \\
\hline
\end{tabular}

\begin{tabular}{|c|c|}
\hline TEKTU & $\begin{array}{c}\text { TEK-ART İNŞAAT TICARET TURİMM } \\
\text { SANAYI VE YATIRIMLAR ANONIM } \\
\text { ŞIRKETI }\end{array}$ \\
\hline UTPYA & $\begin{array}{c}\text { UTOPYA TURIZM İNSSAAT } \\
\text { İSETMECILIK TICARET ANONIM } \\
\text { ŞIRKETİ }\end{array}$ \\
\hline
\end{tabular}

\section{Financial Ratios (Performance Indicators)}

It is aimed to reach a judgment about the economic and financial structure as well as the profitability of the businesses by establishing mathematical relations between the ratio analysis method and the account groups in financial statements. It is possible to calculate multiple ratios from financial statements. However, the aim should be interpretable information. For this reason, the items which have a meaningful relationship are selected and compared with each other. The financial status of the entities is interpreted by comparing the results of previous years or making comparisons with the general standards, as it is common in literature (Çabuk and Lazol, 2011).

Financial ratios used in performance analysis are classified as liquidity ratios, financial ratios, activity ratios and profitability ratios. In this study, liquidity ratios taken into consideration were current ratio and cash ratio. Activity ratios taken into account were stock (inventory) turnover ratio, ownership turnover ratio, sales and cost ratio. Profitability ratios chosen were assets profitability, profitability of equity, profitability and net profit margin.

Liquidity Ratios: They measure the short-term debt solvency of orgnanization; in other words, evaluate the liquidity risk and determine whether the net operating capital is sufficient (Akgüç,1995:346).

Financial Ratios: The ratios used in measuring the short and long term debt repayment power of the resources that constitute the passive part of the enterprise balance sheets are included in this group. Financial ratios 
measure the extent of usage of foreign sources in the financing of an enterprise. Financial ratios with another expression; examine the location of the debt of the business in financial structure and its consequences within this structure (Ataman and Hacırüstemoğlu, 1999:131).

Activity Ratios: They are used to determine how much investment is made relative to the income generated from assets and how efficiently they are used. It is desired that these ratios are high (Ömürberk and Mercan, 2013)

Profitability Ratios: These ratios show whether the company has earned enough profits and from which elements this profit is generated. It is known that the universally accepted income statement includes various income and expenditure items following a specific order from top to the bottom. The profit of each stage has a different meaning in terms of financial status and performance of the organization (Saraç,2012:21).

The financial ratios and calculation methods used in the analysis of the study are shown in Table 3. According to the information in Table 3; determination of the liquidity status of the business is made by determining the current ratio, cash ratio, the stock transfer ratio (inventory turnover ratio) and the ownership turnover ratip in determining the effective use of the assets of the entity and finally the net profit margin, the profitability ratio of the equity, profitability and net sales ratio.

Table 3: Ratios Considered for the Research

\begin{tabular}{|c|c|}
\hline Ratios & Formulas \\
\hline O1: Current Ratio & $\begin{array}{c}\text { Current Assets/ Short Term } \\
\text { Liabilities }\end{array}$ \\
\hline O2:Cash Ratio & $\begin{array}{c}\text { Cash and Cash Equivalents / Short } \\
\text { Term Liabilities }\end{array}$ \\
\hline $\begin{array}{c}\text { O3:Stock (Inventory) } \\
\text { Turnover Rate }\end{array}$ & $\begin{array}{c}\text { Cost of Goods Sold / Average } \\
\text { Inventory }\end{array}$ \\
\hline O4:Return on Equity & Net Sales / Average Equity \\
\hline O5:Equity Profitability & Net Profit / Shareholders' Equity \\
\hline O6:Net Profit Margin & Net Profit / Net Sales \\
\hline O7:Active Profitability & Net Profit / Total Assets \\
\hline $\begin{array}{c}\text { O8:Operational } \\
\text { Profitability }\end{array}$ & Operating Profit / Net Sales \\
\hline
\end{tabular}

\section{Data and Methodology}

The aim of this study is to analyze the performance of the companies in the tourism sector, which are traded on BIST for 2013-2016, taking into account their financial data. For this reason, the TOPSIS analysis is used to determine the best and worst of the business performances.

The TOPSIS method can be applied directly on data without a qualitative conversion. With this method, it is possible to sort out the ideal solution distances between the maximum and minimum values that can be taken by certain criteria. In TOPSIS analysis, Microsoft Office Excel program was used. The data are obtained from the financial statements on the BIST website. Seven companies listed on BIST with full financial statements between 2013-2016 were included in the study.

There are many criteria-based decision making techniques used in businesses. The TOPSIS method is the most common of all-purpose decision making techniques. The TOPSIS method gives meaningful results when evaluating the operating performance. This method is the most suitable solution for operation based on ideal and negative ideal solutions. Positive ideal solution is an improved method based on the assumption that, the nearest negative ideal solution will be formed from the most far point. OPSIS (Technique for Order Preference by Similarity to Ideal Solution) was developed by Hwang \& Yoon (1981) as an alternative to the method of ELECTRE and is the most widely used multi-criteria decision making technique (Kabakçı,2014).

This method consists of 6 steps. The following table summarizes these steps.

Table 4: TOPSIS Analysis Application Steps

\begin{tabular}{|c|c|}
\hline Step 1: & Creating the Decision Matrix \\
\hline Step 2: & The Normalized Decision Matrix Creation \\
\hline Step 3: & Creation of Weighted Decision Matrix \\
\hline Step 4: & Creating Ideal (A +) and Negative Ideal (A) Solutions \\
\hline Step 5: & Calculation of separation measures \\
\hline Step 6: & Calculation of ideal approximation of solution \\
\hline
\end{tabular}

Step 1: Creating the Decision Matrix (A):

The decision matrix contains the decision points to be ranked in the rows and the evaluation factors to be used in decision making in the columns. The decision matrix is shown as follows: In the matrix Aij, $m$ is the number of decision points and $\mathrm{n}$ is the number of evaluation factors (Dumanoğlu and Ergün,2010:105). 


$$
A_{i j}=\left[\begin{array}{cccc}
a_{11} & a_{12} & \ldots & a_{1 n} \\
a_{21} & a_{22} & \ldots & a_{2 n} \\
\cdot & & & \cdot \\
\cdot & & & \cdot \\
\cdot & & & \cdot \\
a_{m 1} & a_{m 2} & \ldots & a_{m m}
\end{array}\right]
$$

Table 5: Annual Standard Decision Matrix for the 2013-2016 Period

\section{Year 2013}

\begin{tabular}{|c|c|c|c|c|c|c|c|c|c|}
\hline $\begin{array}{c}\text { Shar } \\
\mathrm{e}\end{array}$ & 01 & $\mathrm{O} 2$ & $\mathrm{O} 3$ & $\mathrm{O} 4$ & $\mathrm{O}$ & $\mathrm{O}$ & $\mathrm{O}$ & $\mathrm{O}$ & $\mathrm{O}$ \\
\hline $\begin{array}{c}\text { AVT } \\
\text { UR }\end{array}$ & $\begin{array}{c}15, \\
93\end{array}$ & 0,01 & 47,22 & 0,03 & 0,00 & 0,00 & $-0,12$ & 0,59 & $-0,31$ \\
\hline $\begin{array}{c}\text { MAA } \\
\text { LT }\end{array}$ & $\begin{array}{c}12, \\
89\end{array}$ & 12,61 & 44,79 & 0,13 & 0,02 & 0,02 & 0,16 & 0,58 & $-0,11$ \\
\hline $\begin{array}{c}\text { MAR } \\
\text { TI }\end{array}$ & 0,68 & 0,02 & 3,27 & 0,56 & $-0,13$ & $-0,04$ & $-0,21$ & 0,76 & $-0,15$ \\
\hline $\begin{array}{c}\text { MET } \\
\text { UR }\end{array}$ & 2,99 & 0,06 & 0,04 & 0,34 & 4,58 & $-0,22$ & $-10,53$ & 0,90 & $-2,94$ \\
\hline $\begin{array}{c}\text { NTT } \\
\text { UR }\end{array}$ & 0,36 & 0,14 & 15,94 & 0,05 & 0,24 & 0,15 & 4,47 & 0,77 & 1,12 \\
\hline $\begin{array}{c}\text { TEKT } \\
\text { U }\end{array}$ & 2,09 & 0,02 & 159,9 & 0,09 & 0,01 & 0,01 & 0,15 & 0,58 & 0,07 \\
\hline $\begin{array}{c}\text { UTP } \\
\text { YA }\end{array}$ & 0,50 & 0,02 & 14,03 & 0,37 & $-0,20$ & $-0,10$ & $-0,49$ & 0,79 & $-0,02$ \\
\hline
\end{tabular}

Table 6: Annual Standard Decision Matrix for the 20132016 Period

\begin{tabular}{|c|c|c|c|c|c|c|c|c|c|}
\hline \multicolumn{10}{|c|}{ Year 2014 } \\
\hline Share & O1 & O2 & O3 & 04 & 05 & 06 & 07 & 08 & 09 \\
\hline AVTUR & 10,69 & 0,02 & $\begin{array}{c}187, \\
23\end{array}$ & 0,04 & 0,09 & 0,09 & 2,60 & 1,86 & $-0,85$ \\
\hline MAALT & 17,55 & 17,38 & $\begin{array}{c}163, \\
42\end{array}$ & 0,10 & 0,05 & 0,05 & 0,54 & 0,42 & 0,30 \\
\hline MARTI & 0,56 & 0,02 & 4,61 & 0,89 & $-0,57$ & $-0,10$ & $-0,48$ & 0,71 & $-0,04$ \\
\hline METUR & 2,52 & 0,03 & 0,00 & 0,00 & 0,83 & $-0,24$ & 0,00 & 0,00 & 0,00 \\
\hline NTTUR & 3,22 & 2,69 & 17,25 & 0,04 & 0,16 & 0,15 & 4,27 & 0,81 & $-0,11$ \\
\hline TEKTU & 1,42 & 0,05 & 99,04 & 0,09 & 0,01 & 0,01 & 0,15 & 0,49 & 0,05 \\
\hline UTPYA & 0,37 & 0,01 & 30,73 & 0,44 & $-0,01$ & $-0,01$ & $-0,02$ & 0,78 & 0,11 \\
\hline
\end{tabular}

Table 7: Annual Standard Decision Matrix for the 20132016 Period

\section{Year 2015}

\begin{tabular}{|c|c|c|c|c|c|c|c|c|c|}
\hline Share & O1 & O2 & O3 & O4 & O5 & O6 & O7 & O8 & O9 \\
\hline AVTUR & 0,80 & 0,01 & 80,02 & 0,03 & 0,03 & 0,02 & 0,81 & 0,83 & 0,15 \\
\hline MAALT & 10,18 & 10,10 & $\begin{array}{c}181, \\
37\end{array}$ & 0,12 & 0,06 & 0,05 & 0,48 & 0,33 & 0,32 \\
\hline MARTI & 0,35 & 0,01 & 8,54 & 0,40 & $-0,10$ & $-0,05$ & $-0,42$ & 0,79 & $-0,04$ \\
\hline METUR & 10,23 & 0,99 & 0,44 & $\begin{array}{c}37, \\
98\end{array}$ & 1,75 & 0,30 & 0,37 & 0,27 & 0,67 \\
\hline
\end{tabular}

\begin{tabular}{|c|c|c|c|c|c|c|c|c|c|}
\hline NTTUR & 5,18 & 3,96 & 22,14 & 0,04 & 0,06 & 0,05 & 1,56 & 0,80 & $-0,17$ \\
\hline TEKTU & 4,36 & 2,55 & $\begin{array}{c}142, \\
29\end{array}$ & 0,12 & 0,01 & 0,01 & 0,11 & 0,54 & 0,06 \\
\hline UTPYA & 0,66 & 0,03 & 15,93 & 0,35 & $-0,20$ & $-0,09$ & $-0,63$ & 0,85 & $-0,02$ \\
\hline
\end{tabular}

Table 8: Annual Standard Decision Matrix for the 20132016 Period

\section{Year 2016}

\begin{tabular}{|c|c|c|c|c|c|c|c|c|c|}
\hline Share & O1 & O2 & O3 & O4 & O5 & O6 & O7 & O8 & O9 \\
\hline AVTUR & 0,30 & 0,01 & 89,54 & 0,03 & 0,11 & 0,09 & 4,28 & 0,98 & $-1,81$ \\
\hline MAALT & 3,49 & 3,43 & $\begin{array}{c}219, \\
92\end{array}$ & 0,04 & 0,02 & 0,02 & 0,39 & 0,96 & $-1,00$ \\
\hline MARTI & 0,26 & 0,00 & 12,13 & 0,21 & $-0,33$ & $-0,11$ & $-1,10$ & 0,86 & $-0,27$ \\
\hline METUR & 6,86 & 0,93 & 1,28 & 3,49 & 0,46 & 0,40 & 0,17 & 0,73 & 0,22 \\
\hline NTTUR & 1,22 & 0,50 & 27,29 & 0,05 & 0,00 & 0,00 & 0,03 & 0,84 & $-0,24$ \\
\hline TEKTU & 1,88 & 0,12 & 44,97 & 0,02 & $-0,07$ & $-0,04$ & $-4,32$ & 1,03 & $-4,32$ \\
\hline UTPYA & 0,49 & 0,01 & 8,56 & 0,23 & $-0,34$ & $-0,13$ & $-1,27$ & 1,00 & $-0,26$ \\
\hline
\end{tabular}

In our example, 7 businesses from decision points and 9 financial ratios from evaluation factors are used. In the first phase of the study, the Standard Decision Matrix was created for the TOPSIS method. Decision matrix for the years 2013-2016 belonging to the enterprises subject to the study are shown in Table 5, Table 6, Table 7 and Table 8.

Step 2: The Normalized Decision Matrix (R) Creation

The values of rij are calculated using the values in the standard decision matrix with the formula below:

$$
\begin{gathered}
R_{i j}=\frac{a_{i j}}{\sqrt{\sum_{k=1}^{m} a_{k j}^{2}}} \\
(i=1, \ldots, m ; j=1, \ldots, n)
\end{gathered}
$$

In our example; the normalized decision matrices for the years 2013-2016 are calculated and the normalized decision matrix for the year 2013 is shown in Table 9 below.

Table 9: Normalized Decision Matrix of Year 2013

\begin{tabular}{|c|c|c|c|c|c|c|c|c|c|}
\hline $\begin{array}{c}\text { Sha } \\
\text { re }\end{array}$ & $\mathbf{0 1}$ & $\mathbf{0 2}$ & $\mathbf{0 3}$ & $\mathbf{0 4}$ & $\mathbf{0 5}$ & $\mathbf{0 6}$ & $\mathbf{0 7}$ & $\mathbf{0 8}$ & $\mathbf{0 9}$ \\
\hline $\begin{array}{c}\text { AVT } \\
\text { UR }\end{array}$ & 0,765 & 0,001 & 0,271 & 0,040 & $-0,001$ & $-0,010$ & 0,308 & $-0,011$ & $-0,097$ \\
\hline $\begin{array}{c}\text { MA } \\
\text { ALT }\end{array}$ & 0,619 & 1,000 & 0,257 & 0,165 & 0,004 & 0,014 & 0,304 & 0,068 & $-0,034$ \\
\hline $\begin{array}{c}\text { MA } \\
\text { RTI }\end{array}$ & 0,033 & 0,001 & 0,019 & 0,729 & $-0,028$ & $-0,019$ & 0,398 & $-0,134$ & $-0,048$ \\
\hline
\end{tabular}




\begin{tabular}{|c|c|c|c|c|c|c|c|c|c|}
\hline $\begin{array}{l}\text { ME } \\
\text { TUR }\end{array}$ & 0,143 & 0,005 & 0,000 & 0,438 & 0,997 & $-0,919$ & 0,474 & $-0,776$ & $-0,928$ \\
\hline $\begin{array}{l}\text { NTT } \\
\text { UR }\end{array}$ & 0,017 & 0,011 & 0,092 & 0,070 & 0,053 & 0,390 & 0,404 & 0,514 & 0,354 \\
\hline $\begin{array}{l}\text { TEK } \\
\text { TU }\end{array}$ & 0,100 & 0,001 & 0,919 & 0,123 & 0,003 & 0,013 & 0,307 & 0,044 & 0,023 \\
\hline $\begin{array}{l}\text { UTP } \\
\text { YA }\end{array}$ & 0,024 & 0,002 & 0,081 & 0,477 & $-0,043$ & $-0,042$ & 0,415 & $-0,331$ & $-0,007$ \\
\hline $\begin{array}{c}\text { TOT } \\
\text { AL }\end{array}$ & 1,701 & 1,021 & 1,639 & 2,042 & 0,986 & $-0,573$ & 2,610 & $-0,627$ & $-0,736$ \\
\hline
\end{tabular}

Step 3: Creation of Weighted Decision Matrix (V)

In this step, the weight values (wi) related to the evaluation factors are determined, then the elements in each column of the $\mathrm{R}$ matrix are multiplied by the corresponding (wi) values to form the $\mathrm{V}$ matrix (Aladağ et. al. 2016). The formula for the calculation of the matrix $\mathrm{V}$ is shown below:

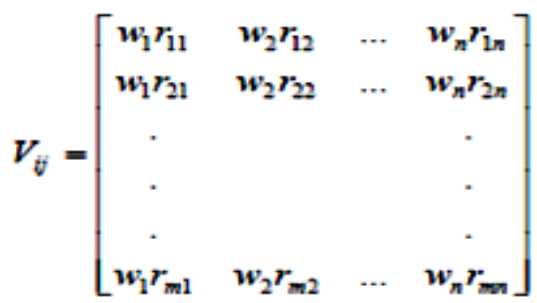

The weights for the evaluation criteria are determined as $\mathrm{W} 1$ and $\mathrm{W} 2$. The weights to be created are for the normalized decision matrix. The values of columns of the $\mathrm{R}$ matrix are multiplied by the corresponding evaluation factor weight values and the columns of the V matrix are calculated.

In our example, weighted normalized decision matrices for 2013-2016 are calculated and the weighted decision matrix for 2013 is shown in Table 7 below:

Table 10: Year 2013 Weighted Normalized Decision Matrix

\begin{tabular}{|c|c|c|c|c|c|c|c|c|c|}
\hline $\begin{array}{c}\text { Shar } \\
\mathbf{e}\end{array}$ & $\mathbf{0 1}$ & $\mathbf{0 2}$ & $\mathbf{0 3}$ & $\mathbf{0 4}$ & $\mathbf{0 5}$ & $\mathbf{0 6}$ & $\mathbf{0 7}$ & $\mathbf{0 8}$ & $\mathbf{0 9}$ \\
\hline $\begin{array}{c}\text { AVT } \\
\text { UR }\end{array}$ & 0,161 & 0,000 & 0,055 & 0,010 & 0,000 & 0,001 & 0,100 & 0,001 & 0,009 \\
\hline $\begin{array}{c}\text { MAA } \\
\text { LT }\end{array}$ & 0,131 & 0,127 & 0,052 & 0,042 & 0,001 & $-0,001$ & 0,099 & $-0,005$ & 0,003 \\
\hline $\begin{array}{c}\text { MAR } \\
\text { TI }\end{array}$ & 0,007 & 0,000 & 0,004 & 0,185 & $-0,003$ & 0,001 & 0,129 & 0,010 & 0,004 \\
\hline $\begin{array}{c}\text { MET } \\
\text { UR }\end{array}$ & 0,030 & 0,001 & 0,000 & 0,111 & 0,122 & 0,065 & 0,153 & 0,060 & 0,085 \\
\hline $\begin{array}{c}\text { NTT } \\
\text { UR }\end{array}$ & 0,004 & 0,001 & 0,019 & 0,018 & 0,006 & $-0,028$ & 0,131 & $-0,040$ & $-0,032$ \\
\hline $\begin{array}{c}\text { TEK } \\
\text { TU }\end{array}$ & 0,021 & 0,000 & 0,187 & 0,031 & 0,000 & $-0,001$ & 0,099 & $-0,003$ & $-0,002$ \\
\hline $\begin{array}{c}\text { UTP } \\
\text { YA }\end{array}$ & 0,005 & 0,000 & 0,016 & 0,121 & $-0,005$ & 0,003 & 0,134 & 0,026 & 0,001 \\
\hline
\end{tabular}

Step 4: Creating Ideal $(\mathrm{A}+)$ and Negative Ideal (A) Solutions

According to the TOPSIS method, each evaluation factor assumes monotone increasing or decreasing tendency. In order to form the ideal solution set, the largest values of the column values are selected by another expression of the weighted evaluation criterion in the $\mathrm{V}$ matrix. The ideal solution set is as follows:

$$
\begin{aligned}
& A^{+}=\left\{V_{1}^{+}, V_{2}^{+}, \ldots \ldots ., V_{j}^{+}, \ldots \ldots ., V_{n}^{+}\right\} \\
& A^{-}=\left\{V_{1}^{-}, V_{2}^{-}, \ldots \ldots ., V_{j}^{-}, \ldots \ldots, V_{n}^{-}\right\}
\end{aligned}
$$

In the formula; $\mathrm{j} 1$ is the maximization of utility, and $\mathrm{j} 2$ is the loss minimization. The composition of the best achievable criterion values is the ideal solution. The negative ideal solution consists of the worst solution value that can be achieved. The application is shown in our sample with the ideal and negative ideal solution table for 2013.

Table 11: Ideal (A+) and Negative Ideal (A) Solution Table For Year 2013

\begin{tabular}{|c|c|c|c|c|c|c|c|c|c|}
\hline Share & 01 & $\mathbf{0 2}$ & $\mathbf{0 3}$ & $\mathbf{0 4}$ & $\mathbf{0 5}$ & $\mathbf{0 6}$ & $\mathbf{0 7}$ & $\mathbf{0 8}$ & $\mathbf{0 9}$ \\
\hline $\begin{array}{c}\text { Ideal } \\
\text { Soluti } \\
\text { on }\end{array}$ & 0,161 & 0,127 & 0,187 & 0,185 & 0,122 & 0,065 & 0,099 & 0,060 & 0,085 \\
\hline $\begin{array}{c}\text { Negat } \\
\text { ive } \\
\text { Ideal } \\
\text { Soluti } \\
\text { on }\end{array}$ & 0,004 & 0,000 & 0,000 & 0,010 & $-0,005$ & $-0,028$ & 0,153 & $-0,040$ & $-0,032$ \\
\hline
\end{tabular}

Step 5: Calculation of separation measures

Following the determination of the ideal points, the maximum and minimum point distance values are found with the help of formulas in this step. In this stage, the distance between the positive ideal solution $(\mathrm{S}+)$ and the negative ideal solution (S-) are calculated for each point. Calculation method is shown in the following form:

$$
\begin{array}{ll}
S_{i}^{+}=\sqrt{\sum_{j=1}^{n}\left(v_{i j}-v_{j}^{+}\right)^{2}} & \mathrm{i}=1,2, \ldots, \mathrm{m} \\
S_{i}^{-}=\sqrt{\sum_{j=1}^{n}\left(v_{i j}-v_{j}^{-}\right)^{2}} & \mathrm{i}=1,2, \ldots, \mathrm{m}
\end{array}
$$

In our example, positive and negative ideal solutions are also shown.

Table 12: 2013 Yearly Positive Ideal Solution Distance Point

\begin{tabular}{|c|c|c|c|c|c|c|c|c|c|}
\hline Share & $\mathbf{0 1}$ & $\mathbf{0 2}$ & $\mathbf{0 3}$ & $\mathbf{0 4}$ & $\mathbf{0 5}$ & $\mathbf{0 8}$ & $\mathbf{0 6}$ & $\mathbf{0 7}$ & $\mathbf{0 9}$ \\
\hline AVTUR & 0,000 & 0,016 & 0,017 & 0,030 & 0,015 & 0,004 & 0,004 & 0,000 & 0,006 \\
\hline MAALT & 0,001 & 0,000 & 0,018 & 0,020 & 0,015 & 0,004 & 0,004 & 0,000 & 0,007 \\
\hline MARTI & 0,024 & 0,016 & 0,034 & 0,000 & 0,016 & 0,002 & 0,004 & 0,001 & 0,006 \\
\hline METUR & 0,017 & 0,016 & 0,035 & 0,005 & 0,000 & 0,000 & 0,000 & 0,003 & 0,000 \\
\hline NTTUR & 0,025 & 0,016 & 0,028 & 0,028 & 0,013 & 0,010 & 0,009 & 0,001 & 0,014 \\
\hline TEKTU & 0,020 & 0,016 & 0,000 & 0,024 & 0,015 & 0,004 & 0,004 & 0,000 & 0,008 \\
\hline UTPYA & 0,024 & 0,016 & 0,029 & 0,004 & 0,016 & 0,001 & 0,004 & 0,001 & 0,007 \\
\hline
\end{tabular}


Table 13: 2013 Yearly Negative Ideal Solution Distance Point

\begin{tabular}{|c|c|c|c|c|c|c|c|c|c|}
\hline Share & $\mathbf{0 1}$ & $\mathbf{0 2}$ & $\mathbf{0 3}$ & $\mathbf{0 4}$ & $\mathbf{0 5}$ & $\mathbf{0 6}$ & $\mathbf{0 7}$ & $\mathbf{0 8}$ & $\mathbf{0 9}$ \\
\hline AVTUR & 0,158 & 0,000 & 0,055 & 0,000 & 0,005 & 0,028 & $-0,054$ & 0,041 & 0,041 \\
\hline MAALT & 0,127 & 0,126 & 0,052 & 0,032 & 0,006 & 0,027 & $-0,055$ & 0,035 & 0,035 \\
\hline MARTI & 0,003 & 0,000 & 0,004 & 0,175 & 0,002 & 0,029 & $-0,025$ & 0,050 & 0,037 \\
\hline METUR & 0,027 & 0,001 & 0,000 & 0,101 & 0,127 & 0,093 & 0,000 & 0,100 & 0,117 \\
\hline NTTUR & 0,000 & 0,001 & 0,019 & 0,008 & 0,012 & 0,000 & $-0,023$ & 0,000 & 0,000 \\
\hline TEKTU & 0,018 & 0,000 & 0,187 & 0,021 & 0,006 & 0,027 & $-0,054$ & 0,037 & 0,030 \\
\hline UTPYA & 0,001 & 0,000 & 0,016 & 0,111 & 0,000 & 0,031 & $-0,019$ & 0,066 & 0,033 \\
\hline
\end{tabular}

Step 6: Calculation of ideal approximation of solution

Ideal and negative ideal separation measures are used to calculate $\left(\mathrm{C}^{*} \mathrm{i}\right)$ the computation of the ideal solution relative of each decision point. The criterion used here is the share of the negative ideal measure in the total measure. Calculation of the ideal approximation to relative solubility is shown below with the help of following formula:

$$
C_{i}^{+}=\frac{S_{i}^{-}}{S_{i}^{-}+S_{i}^{+}} \quad \mathrm{i}=1,2, \ldots, \mathrm{m}
$$

Ideal solution relative affinity values in our example are shown with the help of the table below:

Table 14: Ideal Solution Relative Affinity Values Years 2014 and 2016

\begin{tabular}{|l|c|c|c|c|c|}
\hline \multirow{2}{*}{ Share } & Share & \multicolumn{4}{|c|}{ Year 2014 } \\
\cline { 2 - 6 } & C value & Ranking & & C value & Ranking \\
\hline AVTUR & 0,633 & 4 & AVTUR & 0,712 & 2 \\
\hline MAALT & 0,702 & 2 & MAAT & 0,747 & 1 \\
\hline MARTI & 0,620 & 5 & MARTI & 0,495 & 4 \\
\hline METUR & 0,731 & 1 & METUR & 0 & 7 \\
\hline NTTUR & 0,253 & 7 & NTTUR & 0,609 & 3 \\
\hline TEKTU & 0,634 & 3 & TEKTU & 0,425 & 6 \\
\hline UTPYA & 0,603 & 6 & UTPYA & 0,459 & 5 \\
\hline \multirow{2}{*}{ Share } & Share & & & 2016 & \\
\cline { 2 - 7 } & C value & Ranking & & C value & Ranking \\
\hline AVTUR & 0,665 & 5 & AVTUR & 0,558 & 4 \\
\hline MAALT & 0,828 & 1 & MAALT & 0,750 & 1 \\
\hline MARTI & 0,433 & 6 & MARTI & 0,414 & 7 \\
\hline METUR & 0,812 & 2 & METUR & 0,677 & 2 \\
\hline NTTUR & 0,702 & 4 & NTTUR & 0,489 & 5 \\
\hline TEKTU & 0,707 & 3 & TEKTU & 0,648 & 3 \\
\hline UTPYA & 0,405 & 7 & UTPYA & 0,444 & 6 \\
\hline
\end{tabular}

\section{Results}

The tourism companies traded on BIST were examined in this study. The financial performance for the years 2013-2016 was evaluated by the TOPSIS method using the financial statement information. As a result of the evaluation, METUR in 2013 and MALT in 2014, 2015 and 2016 showed the best performances. MALT also showed the second best performance in 2013. METUR has the best performance in 2013, and also it was in the last place because it did not have any sales activity in 2014. METUR showed the second best performance in other years. The poor performers belong to NTTUR in 2013, METUR in 2014, UTPA in 2015 and MARTI in 2016.

When evaluating the financial performances of the enterprises; it is important to compare the performances of the previous year with those of similar qualities in the same sector. In this way, more accurate results can be achieved by evaluating the past and anticipating the future. By the help of TOPSIS multicriteria decision method, the performances of companies operating in the same sector are assessed and the performances are compared. In the following studies, it is possible to obtain more healthy results by comparing the performances of large scale tourism companies which are not traded in BIST, together with their financial statements.

\section{REFERENCES}

Akgüç,Ö,.(1995),Mali Tablolar Analizi, İstanbul.

Aladağ, Z., Alkan, A., ve Çelik, C. (2016). Otomotiv Sektöründe Faaliyet Gösteren Bir Firmada Tedarikçi Seçimi: Ahp-Bulanık Ahp Ve Topsis Uygulamas1. Beykent Üniversitesi Fen Ve Mühendislik Bilimleri Dergisi, 9(1).

Alptekin,N,.Şıklar,E,.(2009), Türk Hisse Senedi Emeklilik Yatırım Fonlarının Çok Kriterli Performans Değerlendirmesi: Topsis Metodu, Dumlupınar Üniversitesi Sosyal Bilimler Dergisi.

Arslan,.M,. (2017), Yönetim Kararlarında Geçerli Maliyet Analizlerine Alternatif bir Yöntem: Bulanık TOPSIS Yöntemi, Gazi İktisat ve İşletme Dergisi.

Ataman,Ü,.Hacirüstemoğlu,R,.(1999), Yöneticiler için Muhasebe ve Finans Bilgileri,İstanbul.

Borsa İstanbul (2017), http://www.borsaistanbul.com. 
Çabuk,A,.Lazol,İ..(2011),Mali

Tablolar

Analizi,Bursa.

Dumanoğlu, S. ve Ergül, N. (2010), İMKB'de İşlem Gören Teknoloji Şirketlerinin Mali Performans Ölçümü, Muhasebe ve Finansman Dergisi, 48.

Hwang, C.L. and Yoon, K. (1981), Multiple Attribute Decision Making: Methods and Applications. Springer-Verlag, New York.

İlkuçar,M,.Çifçi,A,.(2016), $\quad$ Performance Evaluation of Electricity Generation Companies Traded on BIST According to the Financial Parameters through the Application of TOPSIS Method, International Journal of Social Sciences and Education Research.

İşseveroğlu,G,. Sezer,O,.(2015), Financial Performance of Pension Companies Operating in Turkey with TOPSIS Analysis Method, International Journal of Academic Research in Accounting, Finance and Management Sciences.

Kabakçı,C,.(2014), Tarıma Dayalı Sanayi İşletmelerinde TOPSIS Yöntemi ile Finansal Performan Analizi, Dokuz Eylül Üniversitesi Sosyal Bilimler Enstitüsü Yüksek Lisans Tezi.

KAP (2017), http://www.kap.gov.tr.

Orçun,Ç,.Eren,B,.(2017), TOPSIS Yöntemi ile Finansal Performans Değerlendirmesi: XUTEK Üzerinde Bir Uygulama, Muhasebe ve Finansman Dergisi.

Ömürberk,N,.Mercan,Y,.(2014), İmalat Alt Sektörlerinin Finansal Performanslarının TOPSIS ve ELECTRE Yöntemleri İle Değerlendirilmesi, Çankırı Karatekin Üniversitesi İktisadi ve İdari Bilimler Fakültesi Dergisi.

Ömürberk,V,.Kınay,B,.(2013), Hava Taşımacılığı Sektöründe TOPSIS Yöntemi ile Finansal Performans Değerlendirilmesi, Süleyman Demirel Üniversitesi İktisadi ve İdari Bilimler Dergisi.
Özçelik,H,.Kandemir,B,.(2015), BİST’de İşlem Gören Turizm İşletmelerinin TOPSIS Yöntemi İle Finansal Performanslarının Değerlendirilmesi, Balıkesir Üniversitesi Sosyal Bilimler Enstitüsü Dergisi.

Özen,E,.Yeşildağ,E,.Soba,M,.(2015), TOPSIS Performance Evaluation Measures and Relation Between Financial Ratios and stock Returns, Journal of Economics, Finance and Accounting.

Saldanl1,A,.S1rma,İ..(2014), $\quad$ TOPSIS Yönteminin Finansal Performans Göstergesi Olarak Kullanılabilirliği, Marmara Üniversitesi Öneri Dergisi.

Saraç,M,.Finansal Yönetim,Sakarya.

Soba,M,.Akcanl1,F,.Erem,I..Eren,K,.(2011), IMKB'ye Kayıtlı Taş ve Toprak Alanında Faaliyet Gösteren İşletmemelerin Performanslarının TOPSIS Yöntemi İle Değerlendirilmesi, İstanbul Ticaret Üniversitesi Dergisi.

Soba,M,.Eren,K,.(2011), TOPSIS Yöntemi Kullanılarak Finansal ve Finansal Olmayan Oranlara Göre Performans Değerlendirilmesi, Şehirlerarası Otobüs Sektöründe Bir Uygulama, Sosyal Ekonomik Araştırmalar Dergisi.

Şenel,B,.Şenel,M,.Sarıyar,M,.(2012), Evaluation Of Performance Of Automotive İndustry Companies Traded At Stock Exchange (IMKB) by TOPSIS Methodology, İnterdisciplinary Journal Of Contemporary Research İn Business.

Şit,A,.Ekşi,İ..Hacıevliyagil,N,.(2017), BİST’te Ana Metal Sanayi Endeksinde Faaliyet Gösteren İşletmelerin Finansal Performans Ölçümü:2011-2015 Dönemi, Süleyman Demirel Üniversitesi Vizyoner Dergisi.

Temizel,F,.Bayçelebi,B,.(2016), Finansal Oranların TOPSIS Siralaması ile Yıllık Getiriler Arasındaki İlişki: Tekstil İmalatı Sektörü Üzerine Bir Uygulama, Anadolu Üniversitesi Sosyal Bilimler Dergisi. 
Topaloğlu,E,.(2014), Finansal Kirizlerin BIST

Metal Eşya Endeksinde Faaliyet

Gösteren Firmaların Mali

Performanslarına Etkisinin TOPSIS

Yöntemi İle Ölçülmesi, Yönetim ve

Ekonomi Araştırmaları Dergisi

Tunca,M,.Aksoy,E,.Bülbül,H,.Ömürberk,N,.(2

015) AHP Temelli TOPSIS ve

ELECTRE Yöntemiyle Muhasebe

Paket Programı Seçimi, Niğde Üniversitesi İktisadi ve İdari Bilimler Fakültesi Dergisi.

Türkmen,S,.Çağıl,G,.(2012), İMKB'ye Kote Bilişim Sektörü Şirketlerinin Finansal Performanslarının TOPSIS Yöntemi ile Değerlendirilmesi, Maliye Finans Yaziları.

Uygurtürk,H,.Korkmaz,T,.(2012), Finansal Performansın TOPSIS Çok Kriterli Karar Verme Yöntemi İle Belirlenmesi: Ana Metal Sanayi İşletmeleri Üzerine Bir Uygulama, Eskişehir Osmangazi Üniversitesi İBFF Dergisi.
Yükçü,S,.Atağan,
G,.(2010)
TOPSIS
Yöntemine
göre
Performans
Değerleme, Muhasebe ve Finansman
Dergisi. 